\title{
Geochemical Variability of Surface Sediment in Post-Mining Lakes Located in the Muskau Arch (Poland) and Its Relation to Water Chemistry
}

\author{
Michał Gąsiorowski • Jacek Stienss (1D) \\ Elwira Sienkiewicz • Ilona Sekudewicz
}

Received: 13 August 2020 / Accepted: 17 February 2021 / Published online: 3 March 2021

(C) The Author(s) 2021

\begin{abstract}
Water and sediment chemical compositions were investigated in 75 post-mining lakes in the eastern part of the Muskau Arch region (Western Poland, Central Europe). The lakes, originating from lignite and clay surfaces and underground mining activity, exhibited a wide gradient of physical and chemical water parameters. The most pronounced variability in water parameters was observed in $\mathrm{pH}$ values, conductivity, and oxygen concentration in the mixolimnion and monimolimnion. In addition, the lakes varied in terms of their trophic status, indicated by their dissolved organic carbon (DOC) and phosphorous concentrations. In general, lakes with higher $\mathrm{pH}$ values had higher trophic states, and some even exhibited hypertrophic conditions. The Monte Carlo test indicated that the water $\mathrm{pH}$, phosphorus, DOC, and silicon concentrations could significantly explain the chemical characteristics of sediments.
\end{abstract}

Keywords Lake sediments · Coal mining · AMD . Aluminium · Iron

\section{Introduction}

Coal mining impacts the natural environment in many ways, including landscape changes, waste production,

M. Gąsiorowski · J. Stienss $(\bowtie) \cdot$ E. Sienkiewicz •

I. Sekudewicz

Institute of Geological Sciences, Polish Academy of Sciences,

Twarda St. 51/55, PL-00818 Warszawa, Poland

e-mail: jacek.stienss@twarda.pan.pl water, soil and air contamination, water table changes, and noise pollution (Chadwick et al. 1987; Tiwary 2001; Younger 2004; Bian et al. 2010). The negative impacts of mining were generally neglected until the 1980s. Since the 1980s, multiple mines that strongly affected the environment have been closed. Unfortunately, this has failed to stop the negative effects on the ecosystem, and new hazards have arisen. One of the most significant hazards is the weathering of coal and its host rocks, contributing to the acidity of the ground and surface waters (acid mine drainage (AMD)) (Blowes et al. 2005). AMD is a major water contaminant in numerous post-mining areas in Europe and globally (Williamson et al. 2006). This process can intensify in the near future, leading to several ecological challenges and water unavailability for municipal and industrial purposes (Younger 2002). In addition, AMD has a major impact on lake water and surrounding soils. AMD-affected lakes are commonly known for their high conductivity and increased concentrations of metals such as iron and aluminium (Geller et al. 2013). Acidification of surface waters results in a decline in fish diversity and population. In water bodies impacted by AMD, fish are unable to survive if $\mathrm{pH}$ drops below 5 . Moreover, AMD negatively impacts the diversity and development of aquatic plants and animals (Katz 1969; Sienkiewicz and Gąsiorowski 2016, 2019).

Lake water at sites affected by mining reacts with minerals in the surrounding rocks and soils. Some of these minerals act as a $\mathrm{pH}$ buffer. This leads to natural neutralisation of AMD-affected pit lakes. In general, minerals that play a role in natural neutralisation of 
acidic lakes include calcite, siderite, aluminosilicate, clay, aluminium hydroxysulphate, aluminium and iron hydroxide, and ferrihydrite (Jurjovec et al. 2002; Gunsinger et al. 2006). Although different minerals buffer the solution in different $\mathrm{pH}$ ranges (Blowes and Ptacek 1994), the carbonate system greatly impacts the buffer intensity and the neutralising capacity of water (Langmuir 1997). In addition to the buffering capacity of minerals in bedrock, the neutralisation process of pit lakes depends on many other factors. One of these factors is the age of such lakes and the exposure of sulphides, which are present in the surrounding rocks, to water and aerobic conditions. Although natural neutralisation often begins several decades after the creation of a lake, it can progress relatively quickly (Sienkiewicz and Gąsiorowski 2016).

One of the biggest regions in Central Europe affected by AMD is the Muskau Arch located on the PolishGerman border. Over 100 lakes can be found in postmining pits that developed in former lignite and clay mines. The lignite deposits in the area are of the Oligocene age and were originally deposited at depths of 100 $200 \mathrm{~m}$ (Lutyńska and Labus 2015). Later, they integrated with glacial deposits of large marginal moraine from the Elsterian glaciation (Urbański 2007). The oldest lignite mines in the region began operating in the 1840 s, with some mines closing as early as the end of the nineteenth century (Solski et al. 1988). The closed mines were usually immediately flooded with ground and meteoric waters. Lignite contains large amounts of iron sulphides, for example, pyrite, which easily oxidises in contact with oxygen dissolved in infiltrating water as well as atmospheric oxygen. This process led to the production of sulphuric acid, which resulted in the strong acidification of many anthropogenic lakes in the region (Williamson et al. 2006). The exploitation of lignite in the Polish part of the region ended in 1973 when the 'Babina' mine located in the east of Leknica stopped operating (Koźma 2005). Since then, multiple lakes in the Muskau Arch still show signs of AMD. This is especially apparent in younger lakes, formed 44-49 years ago, exhibiting higher mineralisation and acidity. In addition, the chemical composition of the water from these lakes is characterised by the presence of dissolved compounds of $\mathrm{S}, \mathrm{Si}$, and $\mathrm{Fe}$, which are oxidation products of minerals (e.g. pyrite) from the surrounding rocks (Pukacz et al. 2018). Hence, the oxidation of sulphides has a strong impact on water chemistry, which is greater than that of the dissolution of rock-forming minerals
(Lutyńska and Labus 2015). Furthermore, research has shown that the parameters and concentrations of ion such as $\mathrm{Eh}, \mathrm{SO}_{4}{ }^{2-}, \mathrm{Ca}^{2+}, \mathrm{Mg}^{2+}, \mathrm{Na}^{+}, \mathrm{K}^{+}, \mathrm{Fe}_{\text {org }}, \mathrm{Mn}^{2+}$, and $\mathrm{Al}^{3+}$ increase with the declining $\mathrm{pH}$ levels of lake water (Lutyńska and Labus 2015). Lakes with higher acidity $(\mathrm{pH}<4)$ are characterised by higher concentrations of dissolved $\mathrm{Fe}, \mathrm{Ca}$, and $\mathrm{Mg}$. High concentrations of $\mathrm{Ca}$ and $\mathrm{Mg}$ are due to the dissolution of $\mathrm{Ca}^{2+}$ - and $\mathrm{Mg}^{2+}$-containing minerals (e.g. carbonates silicates) by acidic water (Solski et al. 1988).

This study analysed the chemical composition of water and surface sediments in the 75 lakes situated at the Muskau Arch, with the aim of providing an update on water chemistry studies conducted in the 1980 s (Solski et al. 1988) and to further explain the chemical diversity of these lakes. Employing a dataset on water and sediment chemistry, we attempted to find relationships between specific parameters. We hypothesised that some water parameters in post-mining lakes, such as $\mathrm{pH}$, trophic state, or presence of summer stratification, impacted the composition of bottom sediments. We tested this hypothesis using multivariate analyses and determined the relationship between specific water parameters or elemental content in the water and evaluated water parameters that could explain the chemical composition of the sediment. Understanding the relationship between water and sediment chemistry can help in devising policies for the remediation/protection of post-mining lakes.

\section{Material and Methods}

\subsection{Study Area}

The studied lakes are located in the Muskau Arch in the western part of Poland (Central Europe), close to the border with Germany (Fig. 1). The Muskau Arch is an arch-shaped glaciotectonic moraine formed during the Last Glacial Maximum. This structure is composed of a thick bed of glacial till and some clay and lignite from the Tertiary Period. Lignite occurs as strongly faulted horizons or lenses (Urbański 2007; Lutyńska and Labus 2015). The glacial origin of the structure resulted in a characteristic geomorphology, which was extensively modified by mining activity. Lignite was extracted by the subsurface or surface mining method. Several lakes in the Muskau Arch formed as a result of lignite and clay mining (Solski et al. 1988). 
Post-mining lakes in the region can be divided into two types: depressions created over underground passages and chambers after their collapse and water bodies filling open-mine pits. Lakes of the first type are usually narrow and long, with very steep shores. Lakes of the second type are usually larger and have an irregular shape. In addition, natural lakes related to lignite deposits are also present in the region. These natural lakes formed owing to the weathering of lignite beds and the subsequent lowering of the terrain surface. These basins are relatively small and shallow (Koźma 2005).

\subsection{Fieldwork}

Samples were collected in June and September 2013 and June 2014. The surface sediments were collected from 75 lakes (Fig. 1) at their deepest sites using a Kayak-type gravity corer with a polycarbonate pipe that had a diameter of $55 \mathrm{~mm}$. Only the top 2-cm-thick layer, representing the last 1-4 years (Sienkiewicz and Gasiorowski 2016, 2017 , 2018, 2019), was sampled for geochemical analysis. Sediment samples were stored in plastic bags under dry and cold $\left(4{ }^{\circ} \mathrm{C}\right)$ conditions. Water parameters (temperature, conductivity, $\mathrm{pH}$, dissolved oxygen (DO), and dissolved organic carbon (DOC)) were measured in situ for each sampled lake, using multiparameter MultiLineP4 SET manufactured by WTW, both at the surface and near the bottom, $0.5 \mathrm{~m}$ above the lake bed. In selected lakes (e.g. site 61 ), the water parameters were measured every $1 \mathrm{~m}$ to investigate thermal and chemical stratification. Water samples for laboratory analyses were collected from the top water layer at a depth of $0.5 \mathrm{~m}$ using a 5-L vertical water sampler. Further, the water samples were filtered through a membrane filter with pore size of $0.45 \mu \mathrm{m}$, stored in 50 $\mathrm{mL}$ polyethylene bottles, and transported to the laboratory in a portable fridge under cold $\left(4^{\circ} \mathrm{C}\right)$ conditions.

\subsection{Surface Sediment and Water Analysis}

Sediment samples were weighed and dried at $65{ }^{\circ} \mathrm{C}$ for $48 \mathrm{~h}$ to determine the bulk density and water content. Dry, grounded, and homogenised sediment samples were analysed for selected elements $(\mathrm{Ca}, \mathrm{Al}, \mathrm{Fe}, \mathrm{Mn}, \mathrm{P}$, total nitrogen (TN), total organic carbon (TOC), total hydrogen (TH), and total sulphur (TS)). For elemental analysis, the sediment samples were pre-treated with $10 \%$ hydrochloric acid to dissolve carbonates. Subsequently, TOC, TN, TH, and TS contents of the pre-treated samples were determined using the elemental analyser Vario MicroCUBE at the Institute of Geological Sciences PAS in Warsaw. Sulphanilic acid was used as a standard for analysis, and the typical analytical error was smaller than $0.1 \%$.

For metal analysis, sediment samples were dissolved with a mixture of 65\% nitric acid and 35-38\% hydrochloric acid (3:1) in the microwave mineraliser Magnum V2. Filtered water samples were additionally acidified using 1 $\mathrm{mL}$ of $65 \%$ ultra-pure nitric acid. The TOC in the water samples was measured using the Shimadzu carbon analyser TOC-5000 1997, SS14-5000. The nitrogen concentration in water samples was determined using the Kjeldahl method. The contents of $\mathrm{Na}$ and $\mathrm{K}$ in the sediment and water samples were investigated using flame atomic emission spectroscopy; $\mathrm{Ca}$ and $\mathrm{Mg}$ were investigated using flame atomic absorption spectroscopy (Qz 989 SOLAAR by Unicam), and $\mathrm{Fe}, \mathrm{Si}, \mathrm{Mn}, \mathrm{Al}$, and $\mathrm{P}$ were measured using inductively coupled plasma-optical emission spectrometer (Varian Vista-PRO). All measurements were performed at the Institute of Environmental Protection-National Research Institute in Warsaw.

\subsection{Numerical Analysis}

For data analysis, we used the principal component analysis (PCA) and redundancy analysis (RDA). Prior to the multivariate analysis, 15 water variables (water temperature, $\mathrm{DO}, \mathrm{pH}$, conductivity, $\mathrm{DOC}, \mathrm{Ca}, \mathrm{Mg}, \mathrm{Na}, \mathrm{K}, \mathrm{Fe}, \mathrm{Mn}$, $\mathrm{Al}, \mathrm{P}, \mathrm{Si}$, and $\mathrm{TN}$ ) were standardised using logarithms. This precluded effective visualisation in the dendrogram and scatter biplot. PCA was performed to examine the pattern of variation in the surface and deep water chemistry. RDA was employed to explain the pattern of variation in lake sediment chemistry using water parameters as explanatory variables. The relative importance of explanatory variables was determined using forward selection of the RDA. A Monte Carlo test with 999 unrestricted permutations under a reduced model was run to verify the environmental variables that could significantly explain the variation of the dependent variables. Multivariate analyses were performed using Canoco software (version 5; ter Braak and Šmilauer 2012).

\section{Results}

\subsection{Water Chemistry}

Field measurements of water parameters highlighted the strong variability of water $\mathrm{pH}$ (Suppl. 1). The $\mathrm{pH}$ of the 


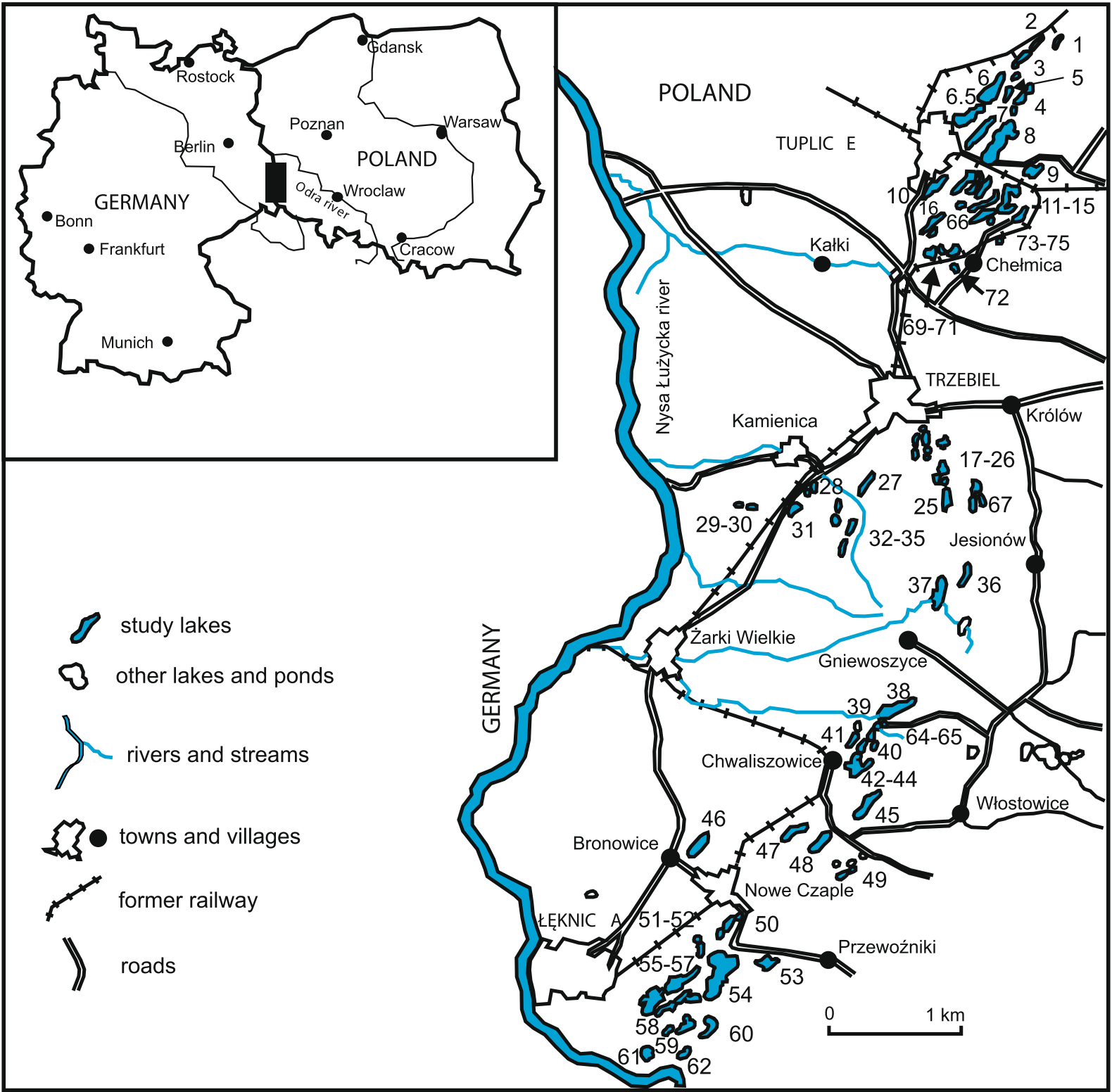

Fig. 1 Location of the studied area and sampled lakes

lake water varied from 2.52 (lake no. 58) to 8.80 (lake no. 68). The lowest $\mathrm{pH}$ was found in lakes formed as a result of lignite mining (2.5-6.0) and the highest was found in post-clay-pit lakes (6.7-8.8) and some natural shallow lakes $(>7.3)$. The collected water samples varied in terms of conductivity, which ranged from 81 $\mu \mathrm{S} \mathrm{cm}^{-1}$ (site 29) in lakes with circumneutral waters to $2430 \mu \mathrm{S} \mathrm{cm}^{-1}$ (site 59) in lakes with acidic water. Water samples from acid lakes were enriched in $\mathrm{Fe}, \mathrm{Al}, \mathrm{Si}, \mathrm{Ca}$, and $\mathrm{Mg}$ (e.g. sites 57, 58), while in samples from alkaline lakes, the concentrations of these elements were significantly lower (e.g. sites 31, 32, 33, 34).

In lake 61 , where clear stratification was observed, $\mathrm{pH}, \mathrm{DO}$, conductivity, and temperature were measured in the water column at 1-m intervals (Fig. 3). Based on the measurements, we determined the presence of the chemocline between 6 and $7 \mathrm{~m}$. At this depth, only temperature changed significantly, but the $\mathrm{pH}$, conductivity, and DO remained almost the same. Below $6 \mathrm{~m}$, the DO began to decline from $7 \mathrm{mg} \mathrm{L}^{-1}$, and at $7 \mathrm{~m}$, it 
was below the detection limit. At $6 \mathrm{~m}$, the $\mathrm{pH}$ and conductivity started to increase, with $\mathrm{pH}$ increasing from 3.04 to 6.52 and conductivity increasing from 1855 to $3070 \mu \mathrm{S} \mathrm{cm}^{-1}$.

PCA was used to determine the factors that contributed the most to the variability in the chemical composition of surface waters (Fig. 2). All environmental variables (water depth, temperature, $\mathrm{DO}, \mathrm{pH}$, conductivity, DOC, Ca, Mg, Na, K, Fe, Mn, Al, P, Si, and N) were included in the analysis. We present results only from the first (PC1) and second (PC2) components (Fig. 2a), which explained $45.9 \%$ and $12.7 \%$ of the variation in the dataset, respectively. PC1 can be primarily explained by the changes in water mineralisation, expressed as conductivity, both in surface and near-tobottom water ( $r=0.98$ and 0.90 , respectively), and the concentration of the main cations. Moreover, changes in water $\mathrm{pH}$ can be observed along the first $\mathrm{PC}$ axis $(r=-$ $0.85)$. The site distribution along PC2 can be interpreted as the variation in nutrient content (i.e. DOC and P; $r=$ 0.64 and 0.69 , respectively) and DO concentration $(r=$ $-0.60)$.

The sites on the PCA plots were divided into two groups with respect to water $\mathrm{pH}$ (acidic and neutral/ alkaline lakes) with a limit value of 5 (Fig. 2b). In addition to grouping according to water $\mathrm{pH}$, three subgroups can be distinguished: (1) lakes with high total mineralisation (expressed as high conductivity, above $1700 \mu \mathrm{S} \mathrm{cm}^{-1}$, and high cation content); (2) relatively deep lakes with high oxygen content in near-to-bottom water; and (3) eutrophic lakes with dissolved carbon content (> $\left.12 \mathrm{mg} \mathrm{L}^{-1}\right)$ and phosphorus $\left(>35 \mu \mathrm{g} \mathrm{L}^{-1}\right)$.

\subsection{Sediment Chemistry}

The collected sediments were classified as sand, mud, sapropel, and detritus gyttja with varying amounts of organic matter. The major and trace element contents, namely, $\mathrm{Al}, \mathrm{Ca}, \mathrm{Fe}, \mathrm{Mn}, \mathrm{P}, \mathrm{TOC}, \mathrm{TH}, \mathrm{TN}$, and TS, were determined in all samples (Suppl. 2). The most prominent feature of the dataset is the high variability of $\mathrm{Al}$ and $\mathrm{Fe}$ concentrations in sediments. The concentrations of these elements were negatively correlated at many sites, that is, lakes with a high concentration of $\mathrm{Al}$ in sediments (e.g. sites 41, 50, 71) had low Fe concentrations, and conversely, sites with high concentrations of $\mathrm{Fe}(3.5,23,51,60)$ had low $\mathrm{Al}$ concentrations $(<10 \mathrm{mg}$ $\mathrm{kg}^{-1}$ ). This relationship is unclear for samples with intermediate concentrations of both elements, resulting in a low overall correlation $(r=0.43)$ between these elements for all datasets (Fig. 4). In the studied sediments, $\mathrm{Mn}$ and $\mathrm{Ca}$ concentrations were positively correlated, as were the concentrations of $\mathrm{P}, \mathrm{C}$, and $\mathrm{N}$. Moreover, the concentration of elements indicating the organic matter content strongly varied between lakes. The highest concentrations of TOC (10-20 wt.\% of dry mass) and TN (up to $3 \%$ of dry mass) were recorded in lakes from the middle part of the region. The absolute maximum TOC (approximately $50 \mathrm{wt} . \%$ of dry mass) was recorded at site 55, comprising sandy sediments full of lignite clasts. The $\mathrm{C} / \mathrm{N}$ ratio for most samples varied between 10 and 20 (Fig. 5). Several samples had C/N ratios in the range of $20-35$, and one had a high $\mathrm{C} / \mathrm{N}$ ratio of 78 (site 55).

\subsection{Explanation of Variations in Lake Sediment by Water Parameters}

The relationship between the sediment and the top-layer water chemistry was tested using ordination techniques. Environmental variables with a large variance inflation factor (VIF > 10), which were conductivity and $\mathrm{Ca}$ concentration, were excluded from the analysis. Because of the relatively short gradients $(0.2 \mathrm{SD})$ in the response dataset, RDA with forward selection was conducted on the sediment data using water parameters as explanatory variables (Fig. 6). The test indicated that only four variables, $\mathrm{pH}, \mathrm{P}, \mathrm{Si}$, and $\mathrm{DOC}$ content, were statistically significant $(p<0.05)$. Together, these variables explained $23.3 \%$ of the variance in the sediment dataset. According to the RDA results, the concentrations of organic matter, $\mathrm{Ca}$, and $\mathrm{Mn}$ in sediments increased with $\mathrm{P}$ content in water. The contents of TOC, $\mathrm{TN}$, and TS in sediments were higher in lakes with a high $\mathrm{pH}$ and DOC content in water. Sedimentary Fe and $\mathrm{Al}$ varied along RDA axis 2, and sedimentary Fe increased with increasing Si concentration in water.

\section{Discussion}

\subsection{Factors Determining Water Chemistry}

The chemistry of water and sediments in the anthropogenic lakes located in the Muskau Arch region was influenced by multiple factors, including the origin of the lake (i.e. coal versus clay mining), the age of the lake (Pukacz et al. 2018), hydrogeological and geological 


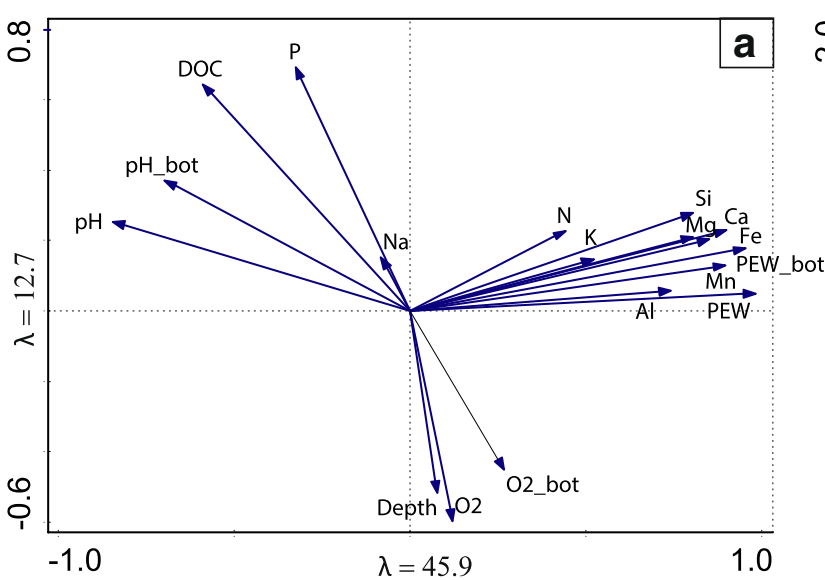

Fig. 2 Principal component analysis (PCA) results from variables characterising lake water chemistry. (A) Scatter plot indicating the position of water parameters on the first two PCA axes and (B) position of the studied lakes with groups defined according to the

conditions, presence of lignite, pyrite content (Labus and Skoczyńska 2013), and ore geometry. This results in high variability in lake water and sediment chemistry, even when comparing closely located sites (Sienkiewicz and Gąsiorowski 2019). Moreover, the complex geological structure of glaciogenic sediments containing lignite makes the changes in the chemistry of the studied lakes difficult to model and predict (Sienkiewicz and Gąsiorowski 2016).

The parameters that significantly differentiate the studied lakes were water conductivity and $\mathrm{pH}$. Moreover, few factors determine the $\mathrm{pH}$ of the studied lakes. Lakes that originate as a result of lignite exploitation usually have a lower $\mathrm{pH}$ than post-clay-pit and natural lakes. This is caused by the oxidation of sulphide compounds present in lignite deposits (Blowes et al. 2005). An important factor influencing the state of water bodies created by lignite mining is their age (Sienkiewicz and Gasiorowski 2016; Pukacz et al. 2018). It is known that the AMD-affected lakes have the ability to neutralise water due to the properties of the clay minerals present in the bedrock (Sienkiewicz and Gasiorowski 2018), the slow weathering of glacial till containing $\mathrm{Ca}$, and the inflow of water with high mineralisation (Stottmeister et al. 1999). However, this is a long process, and in the Muskau Arch, this process is controlled by the time of closure of the lignite mines. The oldest lakes, formed at the beginning of the twentieth century, are located in the northern part of the area near Tuplice (Dawczyk and

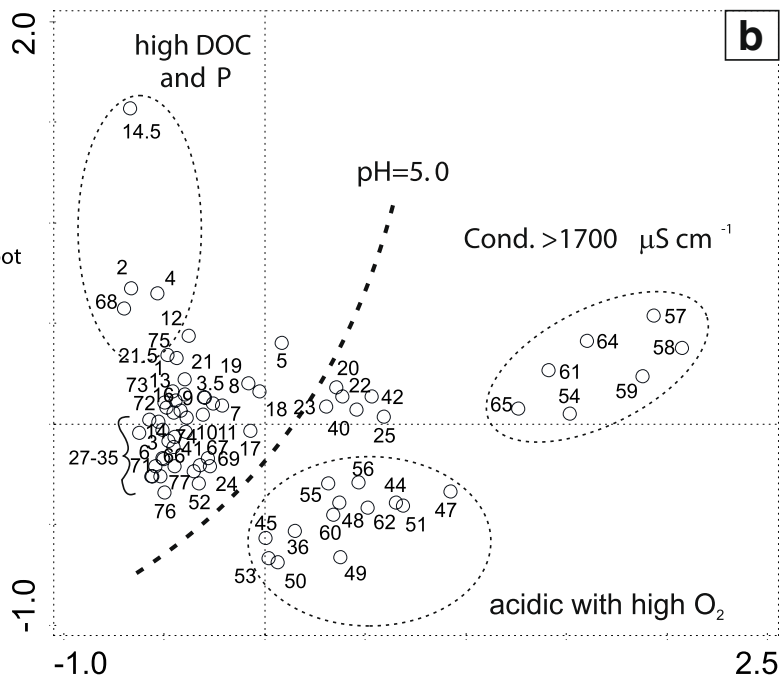

main water characteristics. Codes for water parameters: PEW, water conductivity; $\mathrm{PEW}$ _bot, water conductivity near the bottom; O2 bot, DO concentration near the bottom; $\mathrm{pH}$ bot, $\mathrm{pH}$ near the bottom; Depth, maximum lake depth

Maciantowicz 2014). The $\mathrm{pH}$ of these lakes was significantly higher $(>6)$ than that of the lakes in the central and southern parts of the region (Fig. 2b). The mine closure progressed from north to south. The youngest lakes are on the southern side of the studied area near Leknica. These lakes (sites 38-65, except sites 41 and 52 ), formed in the second half of the twentieth century, are characterised by low $\mathrm{pH}(2.5-4)$, as reported by Lutyńska and Labus (2015). This is owing to the lack of time required for the natural neutralisation of younger water bodies. However, the increased concentration of $\mathrm{Ca}$ in acidic lakes proves the occurrence of the neutralisation process. $\mathrm{CaCO}_{3}$ present in the glacial tills (CaO content 1.8-3.1\%; Maziarz 1980) dissolves in the presence of $\mathrm{H}^{+}$ions and together with $\mathrm{Mg}$ ions $(r=0.76)$ is transported to the lakes. Artificial introduction of calcium hydroxide to a lake is another way of accelerating lake neutralisation (Feng et al. 2019), which was done in the case of lakes 14, 16, 17, 27, 28, and 31 (Oszkinis-Golon et al. 2020). In some other lakes (e.g. lake 10), wastewater was introduced to ensure better conditions for fish breeding.

The high variability in the geological structure of the Muskau Arch resulted in varied water chemistry parameters, even in lakes in close proximity, for example, sites 40 and 42 versus 41 . Site 41 with slightly alkaline water $(\mathrm{pH}=7.44)$ is close to a nearby area with a thick layer of clay, the exploitation of which led to the formation of this lake. It is located only $120 \mathrm{~m}$ from lakes 40 and 42, 
which had water $\mathrm{pH}$ levels of 3.16 and 3.13, respectively. Moreover, even in a single lake, stratification in the water column can result in two chemically different water layers. This process occurs mainly in relatively deep lakes with wind action limited by the direction of their longer axis perpendicular to the dominant wind direction (which in the studied region is west-east). These lakes were stratified based on water density. This is caused by a pronounced temperature gradient caused by changes in weather conditions at the surface of the lakes. This leads to the formation of a thermocline and allows deeper layers that are isolated from the atmosphere to develop chemical conditions different from those in the mixolimnion. Thermal stratification can be strengthened by an inflow of highly mineralised groundwater of a high density directly to the hypolimnion or monimolimnion (Schultze et al. 2016). Examples of such stratification were found in sites 38 (site 24 in Lutyńska and Labus 2015), 54, and 61 (Fig. 3). In these acidic lakes, the hypolimnion water, depleted in DO, had relatively high $\mathrm{pH}$ and conductivity compared to the surface water. This is due to the consumption of oxygen in the near-to-bottom zone by the decomposition of organic matter and reduction of Fe, leading to its dissolution (Boehrer and Schultze 2009). In the mixolimnion and chemocline zones, DO in water results in $\mathrm{Fe}$ and $\mathrm{S}$ oxidation and, consequently, a decrease in $\mathrm{pH}$. A similar pattern of high $\mathrm{pH}$ in the monimolimnion has been observed in stratified acidic pit lakes in other regions (Moser and Weisse 2011; Hrdinka et al. 2013).

In general, acidified water has higher total mineralisation and electroconductivity. Hence, the water conductivity of lignite mining pit lakes is much higher than that of post-clay-pit lakes or natural lakes in the studied area and other regions of Poland (Kostka and Leśniak 2020). This is caused by the hydrolysis of ferric iron during which $\mathrm{H}^{+}$ions are released, affecting the carbonate buffering system, lowering $\mathrm{pH}$, and increasing conductivity (Schultze 2013). Furthermore, the concentration of specific metals is usually higher in acidified water, for example, $\mathrm{Fe}$ and $\mathrm{Al}$ have higher concentrations at low pH (España et al. 2008). Despite this general trend, the concentration of some elements was not significantly correlated with water $\mathrm{pH}$. The $\mathrm{Al}$ concentration is high in water with a $\mathrm{pH}$ below 4 . This $\mathrm{pH}$ is the point below which $\mathrm{Al}$ concentration significantly increased. The Fe concentration is also related to $\mathrm{pH}$ and is the highest in low $\mathrm{pH}$ waters, but decreases gradually rather than abruptly with an increase in $\mathrm{pH}$

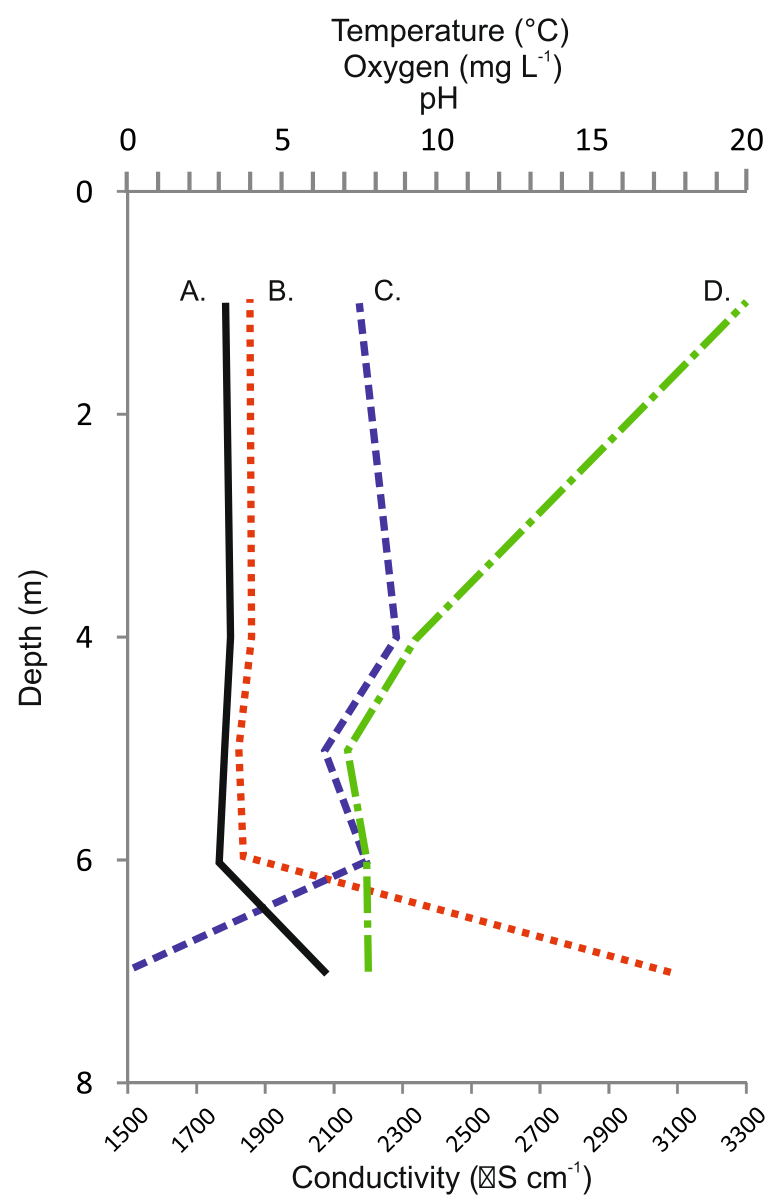

Fig. 3 Profile of water parameters in water column in lake 61. (A) Water $\mathrm{pH}$, (B) conductivity, (C) DO, and (D) temperature

(González et al. 2020). The Mn concentration is also higher in waters below $\mathrm{pH} 4$, which is due to the release of $\mathrm{Mn}$ ions from the reductive dissolution of $\mathrm{Fe}$ and $\mathrm{Mn}$ hydroxides (Torres and Auleda 2013; Åhlgren et al. 2020). Both ferric iron and manganese can still be dissolved in circumneutral waters due to the high solubility of $\mathrm{Fe}^{2+}$ and $\mathrm{Mn}^{2+}$ under anoxic conditions that occur in the hypolimnion in some lakes (e.g. site 38 or 61) or even near-to-surface water of extremely shallow lakes (e.g. site 14.5).

The concentrations of $\mathrm{P}$ and DOC in water are good approximators of the trophic state of lakes. The highest concentrations of $\mathrm{P}$ and DOC were recorded in shallow natural and post-mining lakes (e.g. site 68, 4). These lakes are characterised by strong green algae blooms during the summer despite their shallow depth and oxygen depletion. In addition, zooplankton assemblages indicate eutrophic or hypertrophic conditions (Sienkiewicz and Gąsiorowski 2017, 2019). 
Fig. 4 Correlation between Fe and $\mathrm{Al}$ concentrations in surface sediments of mining lakes in the Muskau Arch region

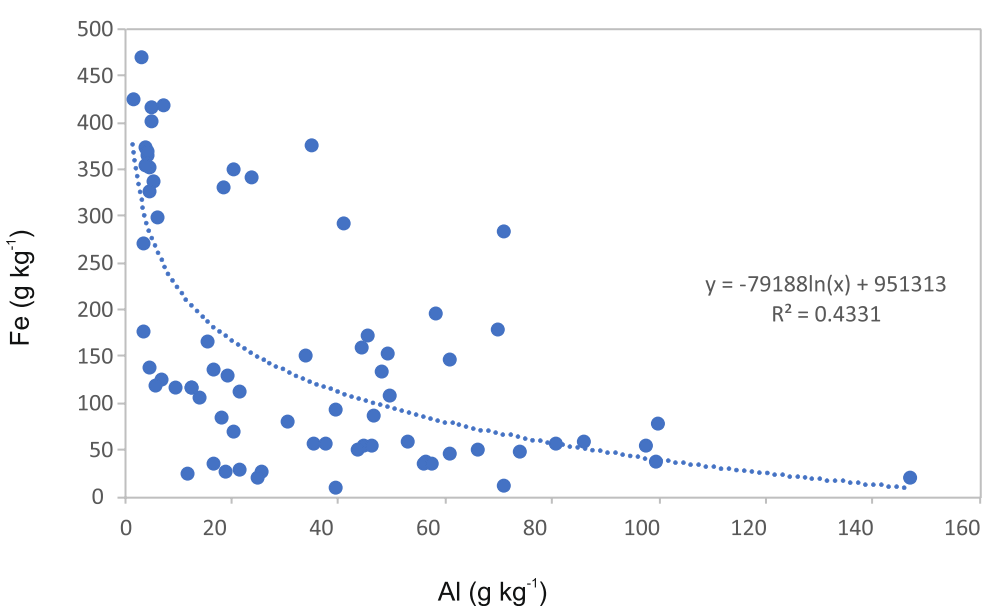

\subsection{Sediment Chemistry in Relation to Water} Parameters

The chemical composition of sediments relies on various reactions occurring in lake ecosystems. It is primarily controlled by reactions occurring in water and detrital material transported to the lake with runoff, groundwater, mass movements, or wind action. The Monte Carlo permutation test indicated that $\mathrm{pH}, \mathrm{Si}, \mathrm{P}$, and DOC could explain the chemical composition of the sediment samples $(p<0.05)$.

The chemical reactions in the studied lakes, including sediment precipitation/dissolution processes, depend highly on water $\mathrm{pH}$. This relationship is evident in the distribution of $\mathrm{Fe}$ and $\mathrm{Al}$ in surface sediments. In general, although the studied sediments displayed high concentrations of $\mathrm{Fe}$ and $\mathrm{Al}$, lake sediments exhibiting high concentrations of $\mathrm{Fe}$ often had low concentrations of $\mathrm{Al}$ and vice versa. The RDA results showed that Fe concentrations in sediments increased with low $\mathrm{pH}$ (e.g. at sites $22,51,57$, and 58). This is possibly related to the precipitation of schwertmannite, goethite, jarosite, and gypsum, which were recognised in lake sediments in this region (Rzepa and Bożęcki 2007). Sites with a high concentration of $\mathrm{Fe}$ are more common in the studied area, especially in the southern part (e.g. sites 22, 51, 57), whereas lakes with sediments enriched in $\mathrm{Al}$ are found mainly in the northern and central parts of the Muskau Arch (e.g. sites 35, 69, 71). Al in lake sediments possibly results from the precipitation of kaolinite and illite (Bożęcki 2013). These lakes are mostly older or were created close to former clay pits and are characterised by circumneutral $(\mathrm{pH}=6.5-7.5)$ waters. This negative correlation results from the characteristic geochemical nature of these elements. Ionic species distribution in water for both $\mathrm{Fe}$ and $\mathrm{Al}$ depends on $\mathrm{pH}$. These metals can exist

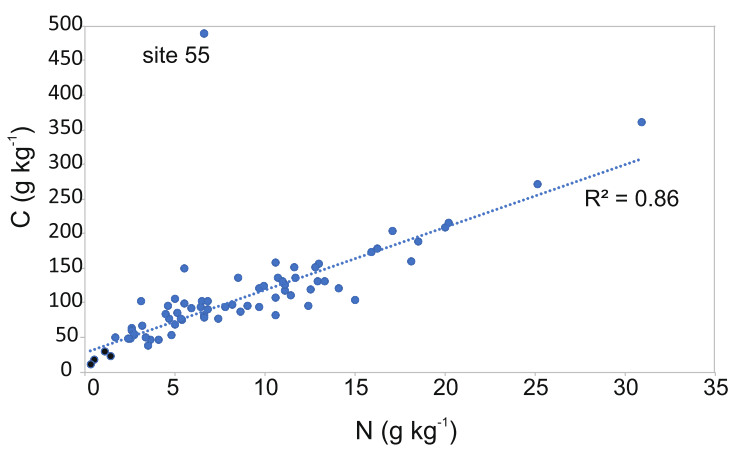

Fig. 5 (A) Correlation between TOC and TN concentrations in sediments of mining lakes in the Muskau Arch region; site 55 that contained numerous lignite particles in sediment was excluded from the analysis. (B) TOC versus $\mathrm{TN}(\mathrm{C} / \mathrm{N})$ ratio in lake sediments in the Muskau Arch; blue bars indicate lakes with dominant

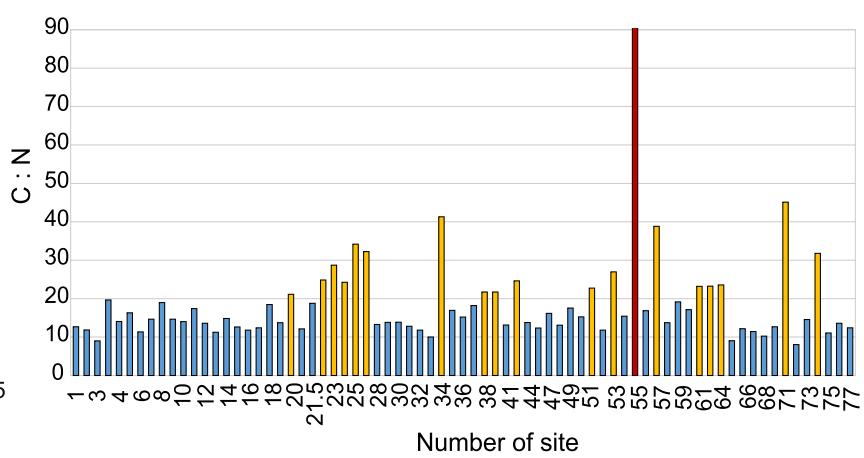

in-lake primary production $(\mathrm{C} / \mathrm{N}<20)$ and orange bars indicate lakes with dominant allochthonous organic matter originating mainly from the lake catchment. Number of lakes are shown in Fig. 1 
Fig. 6 Redundancy analysis (RDA) results summarising relationship of sediment composition and water parameters. Red vectors indicate statistically significant $(p<0.05)$ explanatory variables (water parameters) and blue vectors are sediment parameters. Number of lakes are shown in Fig. 1

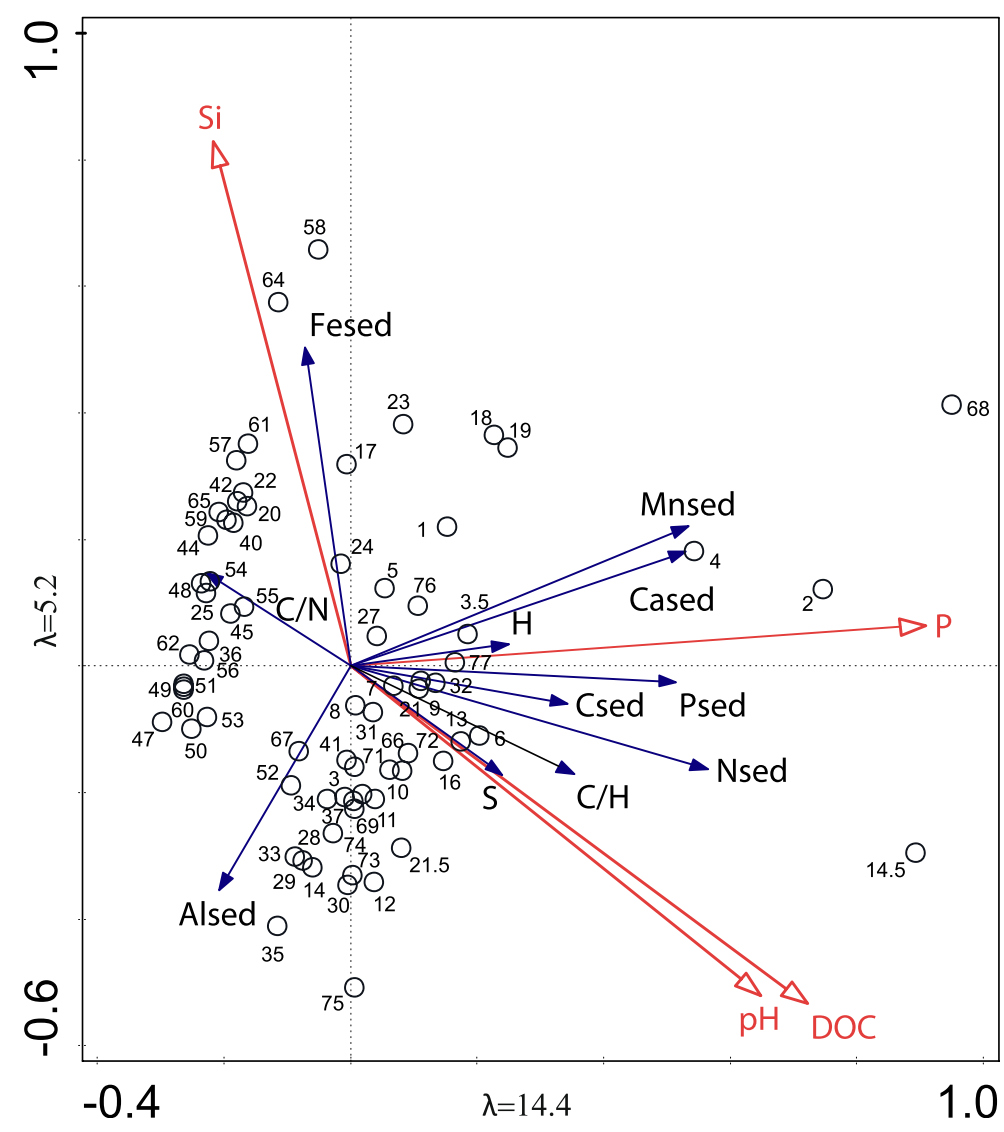

in water in many different forms such as sulphates, hydroxides, or hydroxysulphates. When the $\mathrm{pH}$ of the water increases above $2, \mathrm{Fe}$ compounds begin to precipitate due to hydrolysis, unlike $\mathrm{Al}$ compounds that tend to be hydrolysed and precipitated at $\mathrm{pH}$ 4.5-5.0 (España et al. 2008). Lower concentrations of Fe in sediments also occur in lakes with relatively high Fe content in the water, as well as with thermal stratification and oxygen depletion in the hypolimnion (e.g. sites 14.5, 54, and 57). The water in the bottom layer of these lakes exhibits low concentrations of DO, which indicates anaerobic conditions and the reduction of $\mathrm{Fe}^{3+}$ to $\mathrm{Fe}^{2+}$ ions. $\mathrm{As} \mathrm{Fe}^{2+}$ ions are more soluble than ferric $\mathrm{Fe}$, the reduced $\mathrm{Fe}$ dissolves, enriching the water in this zone and preventing most of the Fe from precipitating into the sediments (Hem and Cropper 1962). This process results in no correlation between the $\mathrm{Fe}$ concentration in water and sediment $(r$ $=0.03$ ).

Although Si was identified in the RDA as one of the drivers controlling sediment chemistry, its relation to sediment parameters is unclear. The $\mathrm{Si}$ in freshwater originates from the weathering of silicate minerals, mainly feldspars. This process occurs mainly in the soil layer under aerobic conditions and is catalysed at low $(<$ 4) and high (> 8) pH (Sverdrup et al. 2019). The Si is transported to the lake as an ion or in a colloid form, and it stays in a liquid form under acidic conditions. Consequently, its concentration is positively correlated with conductivity $(r=0.52)$ and negatively correlated with $\mathrm{pH}(r=-0.70)$. The negative correlation with $\mathrm{pH}$ and weak negative correlation with DOC $(r=-0.37)$ suggest that in neutral and alkaline lakes, which are more productive (e.g. sites 31 or 68 ), at least part of the $\mathrm{Si}$ budget is consumed by diatoms (Sienkiewicz and Gasiorowski 2019) and subsequently deposited into sediments. This process results in a higher concentration of $\mathrm{Si}$ in lakes with low $\mathrm{pH}$ and a simple food web, characterised by sediments rich in iron hydroxides (Fig. 6).

The groups of sites clearly separated on the RDA diagram were eutrophic and hypertrophic lakes (e.g. sites 2, 4, 68). These sites were shallow lakes with sediments enriched in $\mathrm{P}, \mathrm{Mg}, \mathrm{C}$, and N. Furthermore, the $\mathrm{P}$ content in water of these lakes was relatively high, 
exceeding $100 \mu \mathrm{g} \mathrm{L}^{-1}$ in the hypertrophic lake group. Although these lakes are very shallow (maximum depth of 1.5-2 m), oxygen stratification might occur because of the intensive mineralisation of organic matter deposited at their bottom. The organic matter of these lakes, characterised with a low $\mathrm{C} / \mathrm{N}$ ratio $(\sim 10)$, originates almost exclusively from in-lake primary production (Meyers and Teranes 2001). In contrast, some lakes $(34,55,71)$ have a significantly higher $\mathrm{C} / \mathrm{N}$ ratio $(30$ 90 ), suggesting that organic matter in these water bodies mainly originates from their catchment areas. We can assume that lignite deposits in the bedrock of these lakes, or even pieces of lignite leached from the surrounding rocks, may be the cause of the increased $\mathrm{C} / \mathrm{N}$ ratios in the sediments (Blodau et al. 2000).

Analysis of the relationship between water and sediment chemical composition indicated that even small changes in lake characteristics (e.g. changes in oxygen depletion in the hypolimnion or breaking the water stratification) can lead to substantial changes in chemistry. An increase in oxygen concentration can lead to oxidation of $\mathrm{Fe}^{2+}$ cations to less soluble $\mathrm{Fe}^{3+}$ forms or, particularly in eutrophic lakes, to the intensive oxidation of organic matter deposited at the bottom and further eutrophication. These changes might be driven by natural (e.g. weathering of the catchment and carbonate supply) or artificial (e.g. neutralisation with calcium carbonate or sediment dragging) factors. To plan the remediation of these lakes, it is important to identify the chemical characteristics of water and sediments in each lake individually. Because of the high geochemical and biological variability, a universal practice to revitalise these lakes would be ineffective. These lakes are unique ecosystems that need to be protected, at least partially. Hence, a recovery programme should be developed for specific lakes following detailed investigation and monitoring.

\section{Conclusions}

The water and sediment chemical composition of postmining lakes in the Muskau Arch region indicates elevated concentration of some elements, for example, $\mathrm{Al}$ and $\mathrm{Fe}$, compared to lakes in other areas of Central Europe. On the other hand, the concentration of these elements is approximately three orders of magnitude lower compared to other regions impacted by AMD, such as the Iberian Pyrite Belt.
This study has shown that, similar to water, surface sediments of investigated lakes can vary, even in lakes in close proximity. This is especially common in the middle part of the region. It is not surprising that water $\mathrm{pH}$, varying along the gradient in the area, was one of the most important factors explaining the variability in sediment chemical composition. In addition, $\mathrm{P}$ and DOC concentrations indicated the trophic state of the lake and determined its productivity and impact on sediment chemistry. Surprisingly, Fe and Al concentrations or water conductivity (reflecting water total mineralisation) were not statistically significant factors to explain the sediment composition. Future studies should analyse $\mathrm{Fe}$ and $\mathrm{Al}$ speciation or vertical changes in lake water chemistry to identify their relationship with sediment composition.

Supplementary Information The online version contains supplementary material available at https://doi.org/10.1007/s11270021-05057-8.

Acknowledgements The authors thank the employees of the Forest Districts in Lipinki and Lubsko for their kind assistance during the fieldwork. Our colleagues, Agata Jaskółka and Wojtek Sienkiewicz, played an irreplaceable role in sample collection.

Funding This work was supported by the Polish National Science Centre (Grant No. 2012/07/B/ST10/04204).

\section{References}

Åhlgren, K., Sjöberg, V., Grawunder, A., Allard, B., \& Bäckström, M. (2020). Chemistry of acidic and neutralized alum shale pit lakes 50 years after mine closure, Kvarntorp. Sweden. Mine Water and the Environment. https://doi. org/10.1007/s10230-020-00665-y.

Bian, Z., Inyang, H. I., Daniels, J. L., Otto, F., \& Struthers, S. (2010). Environmental issues from coal mining and their solutions. Mining Science and Technology (China), 20, 215-223. https://doi.org/10.1016/S1674-5264(09)60187-3.

Blodau, C., Peine, A., Hoffmann, S., \& Peiffer, S. (2000). Organic matter diagenesis in acidic mine lakes. Acta Hydrochimica et Hydrobiologica, 28(3), 123-135. https://doi.org/10.1002/ 1521-401x(200003)28:3<123::aid-aheh123>3.0.co;2-a.

Blowes, D. W., \& Ptacek, C. J. (1994). Acid-neutralization mechanisms in inactive mine tailings. In D. W. Blowes \& J. L. Jambor (Eds.), The environmental Geochemistry of sulfide mine-wastes (Vol. 22, pp. 271-292). Quebec City: Mineralogical Association of Canada. 
Blowes, D.W., Ptacek, C.J., Jambor, J.L., Weisener, C.G. (2005). Geochemistry of acid mine drainage. In H.D. Holland, S. Lollar, K.K. Turekian (Eds.), Environmental Geochemistry. Treatise on Geochemistry (vol. 9, pp. 149-204). Amsterdam: Elsevier.

Boehrer, B., \& Schultze, M. (2009). Stratification and circulation of pit lakes. In D. N. Castendyk \& E. L. Edmond (Eds.), Mine pit lakes: characteristics, predictive modeling and sustainability (pp. 45-60). Englewood: Society for Mining, Metallurgy, and Exploration.

Bożęcki, P. (2013). Studium osadów tworzacych się w obszarze eksploatacji wegla brunatnego $w$ rejonie Łęknicy (Łuk Mużakowa) (in Polish). Kraków: Akademia GórniczoHutnicza im. Stanisława Staszica.

Chadwick, M. J., Highton, N. H., \& Lindman, N. (1987). Environmental impacts of coal mining and utilization (1st ed.). A Complete Revision of Environmental Implications of Expanded Coal Utilization. Oxford: Pergamon Press.

Dawczyk, G., \& Maciantowicz, M. (2014). Dawne górnictwo $i$ kolejnictwo na terenie Łuku Mużakowa-Aus der Geschichte des Bergbaus Und der Bahn im Muskauer Faltenbogen (Former mining and railway in the area of the Muskau Arch) (in Polish, English summary). Żary: Drukarnia Chroma.

España, J. S., Pamo, E. L., Pastor, E. S., \& Ercilla, M. D. (2008). The acidic mine pit lakes of the Iberian Pyrite Belt: An approach to their physical limnology and hydrogeochemistry. Applied Geochemistry, 23, 1260-1287. https://doi.org/10.1016/j. apgeochem.2007.12.036.

Feng, Y., Wang, J., Bai, Z., \& Reading, L. (2019). Effects of surface coal mining and land reclamation on soil properties: A review. Earth-Science Reviews, 191, 12-25.

Geller, W., Schultze, M., Kleinmann, R., \& Wolkersdorfer, C. (2013). Acidic pit lakes: The legacy of coal and metal surface mines. Heidelberg: Springer - Verlag, Berlin, Heidelberg.

González, R. M., Cánovas, C. R., Olías, M., \& Macías, F. (2020). Seasonal variability of extremely metal rich acid mine drainages from the Tharsis mines (SW Spain). Environmental Pollution, 259, 113829.

Gunsinger, M. R., Ptacek, C. J., Blowes, D. W., \& Jambor, J. L. (2006). Mechanisms controlling acid neutralization and metal mobility within a Ni-rich tailings impoundment. Applied Geochemistry, 21, 1301-1321. https://doi.org/10.1016/j. apgeochem.2006.06.006.

Hem J.D., Cropper W.H. (1962). Chemistry of iron in natural water, survey of ferrous-ferric chemical equilibria and redox potentials. Geological Survey Water-Supply Paper, A, 1459. https://oi.org/10.3133/wsp1459A

Hrdinka, T., Šobr, M., Fott, J., \& Nedbalová, L. (2013). The unique environment of the most acidified permanently meromictic lake in the Czech Republic. Limnologica, 43, 417-426. https://doi.org/10.1016/j.limno.2013.01.005.

Jurjovec, J., Ptacek, C. J., \& Blowes, D. W. (2002). Acid neutralization mechanisms and metal release in mine tailings: a laboratory column experiment. Geochimica et Cosmochimica Acta, 66(9), 1511-1523. https://doi. org/10.1016/S0016-7037(01)00874-2.

Katz, M. (1969). The biological and ecological effects of acid mine drainage with particular emphasis to the waters of the Appalachian region. Washington: U.S. Govt. Print. Off.
Kostka, A., \& Leśniak, A. (2020). Spatial and geochemical aspects of heavy metal distribution in lacustrine sediments, using the example of Lake Wigry (Poland). Chemosphere, 240, 124879 .

Koźma, J. (2005). Zagospodarowanie kopalin towarzyszących na przykładzie obszaru dawnego górnictwa węgla brunatnego rejonu projektowanego Geoparku Łuk Mużakowa. Górnictwo Odkrywkowe, 2, 64-70.

Labus, K., \& Skoczyńska, S. (2013). Origin of sulphates in postmining lakes in the eastern part of the Muskau Arch (PolishGerman border land). Geological Quarterly, 57(3), 561-566. https://doi.org/10.7306/gq.1110.

Langmuir, D. (1997). Carbonate chemistry. In D. Langmuir (Ed.), Aqueous environmental geochemistry (pp. 193-230). New Jersey: Prentice Hall.

Lutyńska, S., \& Labus, K. (2015). Identification of processes controlling chemical composition of pit lakes waters located in the eastern part of Muskau Arch (Polish-German borderland). Archives of Environmental Protection, 41, 60-69. https://doi.org/10.1515/aep-2015-0031.

Maziarz, E. (1980). Ocena surowców glinokrzemianowych eksploatowanych w PMO oraz łupków ogniotrwałych z KWK Nowa Ruda. Mat. Ogn, 32(5), 142-146.

Meyers, P. A., \& Teranes, J. L. (2001). Sediment organic matter. In W. M. Last \& J. P. Smol (Eds.), Tracking Environmental Change Using Lake Sediments (pp. 239-269). Dordrecht: Kluwer Academic Publishers.

Moser, M., \& Weisse, T. (2011). The most acidified Austrian lake in comparison to a neutralized mining lake. Limnologica, 41, 303-315. https://doi.org/10.1016/j.limno.2011.01.002.

Oszkinis-Golon, M., Frankowski, M., Jerzak, L., \& Pukacz, A. (2020). Physicochemical differentiation of the Muskau Arch pit lakes in the light of long-term changes. Water, 12, 2368. https://doi.org/10.3390/w12092368.

Pukacz, A., Oszkinis-Golon, M., \& Frankowski, M. (2018). The physico-chemical diversity of pit lakes of the Muskau Arch (Western Poland) in the context of their evolution and genesis. Limnological Review, 18, 115-126. https://doi. org/10.2478/limre-2018-0013.

Rzepa, G., \& Bożęcki, P. (2007). Mineral composition of AMD precipitates in the Łęnnica region (the Muskau Arch, western Poland). Mineralogia Polonica Special Papers, 31, 243-246.

Schultze, M. (2013). Limnology of pit lakes. In: W. Geller, M Schultze, R. Kleinmann, C. Wolkersdorfer (Eds.) Acid pit lakes. The legacy of coal and metal surface mines (pp. 23224). Heidelberg: Springer - Verlag, Berlin, Heidelberg.

Schultze, M., Boehrer, B., \& Espana, J. S. (2016). On the relevance of meromixis in pit lakes - an update. In C. Drebenstedt \& M. Paul (Eds.), IMWA 2016 - Mining Meets Water Conflicts and Solutions. Medienzentrum of TU Bergakademie Freiberg: Freiberg.

Sienkiewicz, E., \& Gąsiorowski, M. (2016). The evolution of a mining lake - From acidity to natural neutralization. Science of the Total Environment, 557-558, 343-354. https://doi. org/10.1016/j.scitotenv.2016.03.08.

Sienkiewicz, E., \& Gąsiorowski, M. (2017). The diatom-inferred $\mathrm{pH}$ reconstructions for a naturally neutralized pit lake in south-west Poland using the mining and the combined $\mathrm{pH}$ training sets. Science of the Total Environment, 605-606, 7587. https://doi.org/10.1016/j.scitotenv.2017.06.171. 
Sienkiewicz, E., \& Gąsiorowski, M. (2018). The influence of acid mine drainage on phyto- and zooplankton communities in a clay pit lake in the Luk Mużakowa Geopark (western Poland). Fundamental and Applied Limnology, 191, 143154.

Sienkiewicz, E., \& Gąsiorowski, M. (2019). Natural evolution of artificial lakes formed in lignite excavations based on diatom, geochemical and isotopic data. Journal of Paleolimnology, 62, 1-13. https://doi.org/10.1007/s10933-019-00069-1.

Solski, A., Jędrczak, A., \& Matejczuk, W. (1988). Skład chemiczny wód zbiorników pojezierza antropogenicznego w rejonie Tuplice-Łęknica (in Polish). Zeszyty Naukowe Uniwersytetu Zielonogórskiego, 84, 65-76.

Stottmeister, U., Glässer, W., Klapper, H., Weißbrodt, E., Eccarius, B., Kennedy, C., Strauch, G. (1999). Strategies for remediation of former opencast mining areas in Eastern Germany. Environmental impacts of mining activities Emphasis on mitigation and remedial measures. Heidelberg: Springer - Verlag, Berlin, Heidelberg.

Sverdrup, H. U., Oelkers, E., Erlandsson Lampa, M., Belyazid, S., Kurz, D., \& Akselsson, C. (2019). Weathering of silicate minerals in soils and watersheds: Parameterization of the weathering kinetics module in the PROFILE and ForSAFE models. Biogeosciences Discussions. https://doi.org/10.5194 /bg-2019-38.

ter Braak, C.J.F., Šmilauer, P. (2012). Canoco reference manual and user's guide: Software for ordination (version 5.0). Ithaca USA: Microcomputer Power - 496.
Tiwary, R. K. (2001). Environmental impact of coal mining on water regime and its management. Water, Air, and Soil Pollution, 132, 185-199. https://doi.org/10.1023 /A:1012083519667.

Torres, E., \& Auleda, M. (2013). A sequential extraction procedure for sediments affected by acid mine drainage. Journal of Geochemical Exploration, 128, 35-41. https://doi. org/10.1016/j.gexplo.2013.01.012.

Urbański, K. (2007). The zones of glaciotectonical deformation in Muskau arc region (in Polish). Zeszyty Naukowe Uniwersytetu Zielonogórskiego, Seria: Inżynieria Środowiska, 134, 179-190.

Williamson, M. A., Kirby, C. S., \& Rimstidt, J. D. (2006). Iron dynamics in acid mine drainage. Journal American Society of Mining and Reclamation, 2411-2423.

Younger, P. L. (2002). Coalfield closure and the water environment in Europe. Mining Technology, 111, 201-209. https://doi.org/10.1179/mnt.2002.111.3.201.

Younger, P. L. (2004). Environmental impacts of coal mining and associated wastes: a geochemical perspective. Geological Society, London, Special Publications, 236, 169-209. https://doi.org/10.1144/GSL.SP.2004.236.01.12.

Publisher's Note Springer Nature remains neutral with regard to jurisdictional claims in published maps and institutional affiliations. 